\title{
Article/Artigo
}

\section{Phlebotomine sandflies fauna (Diptera: Psychodidae) at rural settlements in the municipality of Cáceres, State of Mato Grosso, Brazil}

\author{
Fauna flebotomínica (Diptera: Psychodidae) em assentamentos rurais no Município de \\ Cáceres, Estado de Mato Grosso, Brasil
}

\begin{abstract}
Graziella Borges Alves ${ }^{1}$, Elisa Teruya Oshiro² ${ }^{2}$ Marcio da Cruz Leite ${ }^{3}$, Aline Vidor Melão ${ }^{3}$, Letícia Moraes Ribeiro ${ }^{2}$, Nathália Lopes Fontoura Mateus ${ }^{2}$, Reginaldo Peçanha Brazil ${ }^{4}$, José Dilermando Andrade Filho ${ }^{5}$ and Alessandra Gutierrez de Oliveira ${ }^{1,2}$
\end{abstract}

\section{ABSTRACT}

Introduction: Leishmaniasis is expanding across Brazil, including the State of Mato Grosso (MT). The aim of this study was to characterize the phlebotomine sandfly fauna at three rural settlements located in the municipality of Cáceres, MT, from August 2010 to July 2011 Methods: Sandfly captures were conducted at the forest border and in intra and peridomicile areas with automatic light traps, biweekly, from $5 \mathrm{pm}$ to $6 \mathrm{am}$. Results: Of the 630 sandflies collected, 348 were female, and 282 were male. Captured specimens were distributed across 11 genera - Brumptomyia, Evandromyia, Expapillata, Lutzomyia, Martinsmyia, Micropygomyia, Nyssomyia, Pintomyia, Psathyromyia, Psychodopygus, and Sciopemyia - and 28 species. Among these, six species had not been marked yet in MT (Brumptomyia avellari, Br. mangabeirai, Evandromyia aldafalcaoae, Micropygomyia echinatopharynx, Micropygomyia peresi, and $\mathrm{Pa}$. campograndensis). Nyssomyia whitmani was the most abundant species across ecotopes at all settlements. Interestingly, Lutzomyia longipalpis and Lutzomyia cruzi were found in sympatry. Conclusions: The disorganized occupation of the environment that is happening at the rural settlements of Mata Comprida, Laranjeira I and II could provide opportunities for the domiciliation of wild populations of phlebotomine, including vectors of leishmaniasis. Therefore, more studies are needed to understand the epidemiology of the disease in these areas and its impact on the human population.

Keywords: Mato Grosso. Phlebotomine fauna. Nyssomyia whitmani. Rural settlement.

\section{RESUMO}

Introdução: As leishmanioses encontram-se em expansão no Brasil, inclusive no Estado de Mato Grosso (MT). A presente pesquisa teve como objetivo estudar a fauna flebotomínica em três assentamentos rurais localizados no município de Cáceres, MT, entre agosto de 2010 e julho de 2011. Métodos: As coletas foram realizadas na margem da mata, no intra e peridomicílio com armadilhas automáticas luminosas, quinzenalmente, das $17 \mathrm{~h}$ às $6 \mathrm{~h}$. Resultados Foram coletados 630 exemplares, sendo 348 fêmeas e 282 machos. Os espécimes foram distribuídos em 11 gêneros: Brumptomyia, Evandromyia, Expapillata, Lutzomyia, Martinsmyia Micropygomyia, Nyssomyia, Pintomyia, Psathyromyia, Psychodopygus e Sciopemyia e 28 espécies, sendo que dentre estas, seis não haviam sido assinaladas em MT (Brumptomyia avellari, Br. mangabeirai, Evandromyia aldafalcaoae, Micropygomyia echinatopharynx, Micropygomyia peresi e Pa. campograndensis). Ressalta-se o encontro de Nyssomyia whitmani, espécie mais abundante nos diferentes ecótopos em todos os assentamentos. Destaca-se também a presença das espécies Lutzomyia longipalpis e Lutzomyia cruzi em simpatria. Conclusões: A ocupação desordenada do ambiente, como vem ocorrendo nos assentamentos Mata Comprida, Laranjeira I e II, pode proporcionar a domiciliação de populações selváticas de flebotomíneos, dentre estes os vetores das leishmanioses, tornando-se necessários maiores estudos para entender a dinâmica de transmissão dessas morbidades nestes locais.

Palavras-chaves: Mato Grosso. Fauna flebotomínea. Nyssomyia whitmani. Assentamento rural.

1. Programa de Pós-Graduação em Doenças Infecciosas e Parasitárias, Universidade Federal do Mato Grosso do Sul, Campo Grande, MS. 2. Laboratório de Parasitologia Humana, Centro de Ciências Biológicas e da Saúde, Universidade Federal do Mato Grosso do Sul, Campo Grande, MS. 3. Curso de Ciências Biológicas, Universidade Estadual de Mato Grosso, Cáceres, MT. 4. Departamento de Bioquímica e Biologia Molecular, Instituto Oswaldo Cruz, Fundação Oswaldo Cruz, Rio de Janeiro, RJ. 5. Coleção de Flebotomíneos, Centro de Referência Nacional e Internacional para Flebotomíneos, Centro de Pesquisas René Rachou, Fundação Oswaldo Cruz, Belo Horizonte, MG.

Address to: Dra. Alessandra Gutierrez de Oliveira. Lab. Parasitologia Humana/CCBS/UFMS. Cidade Universitária s/n, 79070-900 Campo Grande, MS, Brasil.

Phone: 5567 3345-7390

e-mail: alessandra.oliveira@ufms.br

Received in 29/07/2011

Accepted in 03/11/2011

\section{INTRODUCTION}

Leishmaniases are zoonoses transmitted by phlebotomine sandflies (Diptera: Psychodidae) $)^{1,2}$ and caused by parasites of the genus Leishmania, which can parasitize different orders of mammals. Human infection occurs as a consequence of the ecological relationship between parasites and vectors. Therefore, any change in the environment can result in modifications of the parasite distribution ${ }^{3}$.

In the State of Mato Grosso (MT), the presence of the following species has been reported: Lutzomyia cruzi, Lutzomyia longipalpis, and Lutzomyia whitmani. They were found in three biomes (Amazon rainforest, savannah, and Pantanal $)^{4}$. All the 141 cities from the State have recorded autochthonous cases of the integumental form of the disease in these three ecosystems $s^{5}$, and the human visceral form is distributed in 34 municipalities of the State of Mato Grosso, with higher prevalence in the south-central and southeast regions of the State ${ }^{6}$.

Given the growing incidence and geographic spread of leishmaniasis, as well as the importance of the phlebotomine sandflies in the transmission of Leishmania species, this research aimed to analyze the phlebotomine sandfly fauna (Diptera: Psychodidae) in three rural settlements at the municipality of Cáceres, State of Mato Grosso, with a view to developing better control measures.

\section{METHODS}

Cáceres is $209.7 \mathrm{~km}$ from the State capital, Cuiabá, and has the coordinates, S 16 13' 42" W $57^{\circ}$ $40^{\prime} 51^{\prime \prime}$. The city has an altitude of $118 \mathrm{~m}$ above sea level ${ }^{7}$. It is located in the south of the State and east of the Paraguai River and has an area of $24,351,446 \mathrm{~km}^{2}$, an estimated urban population of 87,942 inhabitants, and three biomes: savannah, Amazon, and Pantanal ${ }^{8}$.

The mean annual temperature is $22.6^{\circ} \mathrm{C}$, and the climate is more pleasant in July with mean temperature of $19.1^{\circ} \mathrm{C}$. January is hot with a mean 
temperature of $26.4^{\circ} \mathrm{C}$. The city presents annual pluvial precipitation of $1,370 \mathrm{~mm}$, with the rainy season occurring between October and March, and in the other months, the climate becomes very dry. Humidity can reach up to $10 \%$ in August ${ }^{8}$.
This study was conducted from August 2010 to July 2011 at three rural settlements, Laranjeiras I and II, and Mata Comprida in the municipality of Cáceres (Figure 1). The settlements are located in the northwest of the State of Mato Grosso, near the BR 070 Cuiabá-Porto Velho

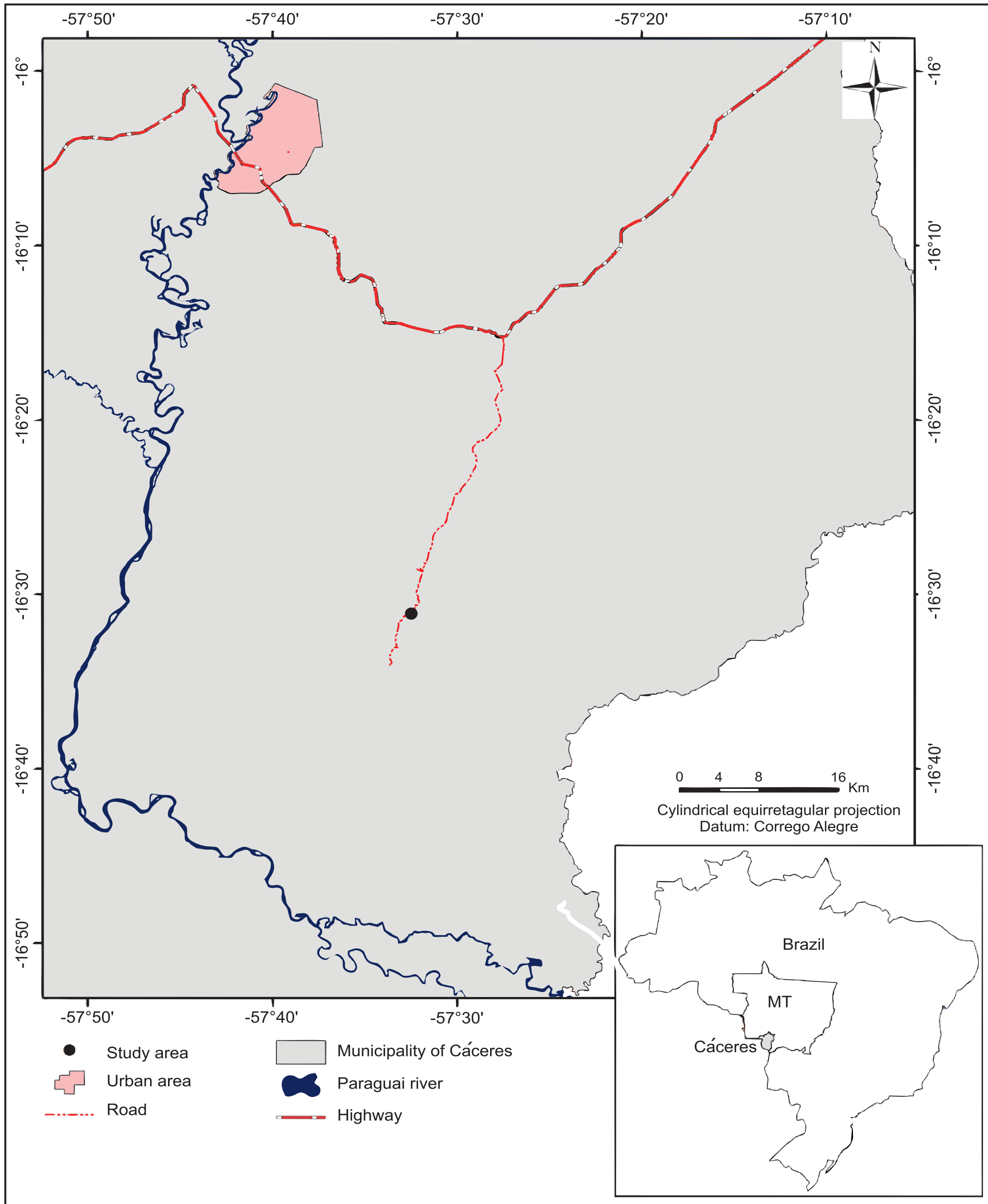

FIGURE 1 - Municipality of Cáceres, State of Mato Grosso, Brazil. 
highway, at the west side of Mangaval mountain range, $70 \mathrm{~km}$ away from the urban area of the municipality. The occupied area of Laranjeira I, which was founded in 1988 , is $108,523,712 \mathrm{~km}^{2}$, and Pantanal biome is the prevalent vegetation. Laranjeira II holds an area of $11,928,120 \mathrm{~km}^{2}$ and was founded in $1987^{9}$. Mata Comprida has $34,448,425 \mathrm{~km}^{2}$ and was founded in 1988 (PA Cunha: personal communication, 2011). The latter two places are characterized as savannah ${ }^{10}$.

In each settlement, three houses were chosen at random. Each had animals (dogs, chickens, pigs, horses, and others) and is near a forest. The captures were conducted at the forest border, and intra and peridomicile areas were with automatic light traps (Falcão model) ${ }^{11}$ biweekly, from $5 \mathrm{pm}$ to $6 \mathrm{am}$.

Captured sandflies were sent to the laboratories of the Regional Health Office of Cáceres (ERSC) and Human Parasitology Laboratory of the Federal University of Mato Grosso do Sul (UFMS), separated, clarified, mounted, and identified according to the nomenclature of Galati ${ }^{2}$. The abbreviations of the genus follow the proposal of Marcondes ${ }^{12}$.
For the evaluation of the most abundant species as well as its spatial distribution, the index of species abundance was converted into a zero-to-one scale through the Standardized Index of Species Abundance (SISA). In this index, value 1 corresponds to the most abundant species ${ }^{13}$. The comparison of the frequencies among the phlebotomine populations, for the different regions and ecotopes, was conducted using chi-squared tests $\left(\chi^{2}\right.$ for the contingency and absolute frequency tables).

\section{RESULTS}

Six hundred and forty-eight biweekly captures were conducted in the settlements of Laranjeira I, Laranjeira II, and Mata Comprida. Of the 630 specimens collected, 348 were females and 282 were males. Table 1 shows the distribution of the phlebotomine fauna present at these three settlements.

The total male: female ratio was $0.81: 1$, and the most abundant species collected in three settlements were 0.92:1 for Nyssomyia

TABLE 1 - Distribution of the phlebotomine species collected with Centers for Disease Control (CDC) traps, by sex, at the settlements Laranjeira I, Laranjeira II, and Mata Comprida, municipality of Cáceres, State of Mato Grosso, Brazil, from August 2010 to July 2011 (n=630).

\begin{tabular}{|c|c|c|c|c|c|c|c|c|c|c|c|c|c|c|c|c|c|c|c|c|c|}
\hline \multirow[b]{3}{*}{ Species } & \multicolumn{6}{|c|}{ Laranjeira I } & \multicolumn{6}{|c|}{ Laranjeira II } & \multicolumn{6}{|c|}{ Mata Comprida } & & & \\
\hline & \multicolumn{2}{|c|}{ Intradomicile } & \multicolumn{2}{|c|}{ Peridomicile } & \multicolumn{2}{|c|}{ Forest } & \multicolumn{2}{|c|}{ Intradomicile } & \multicolumn{2}{|c|}{ Peridomicile } & \multicolumn{2}{|c|}{ Forest } & \multicolumn{2}{|c|}{ Intradomicile } & \multicolumn{2}{|c|}{ Peridomicile } & \multicolumn{2}{|c|}{ Forest } & \multicolumn{2}{|c|}{ Total } & \multirow[b]{2}{*}{$\%$} \\
\hline & $\mathbf{M}$ & $\mathbf{F}$ & M & $\mathbf{F}$ & $\mathbf{M}$ & $\mathbf{F}$ & $\mathbf{M}$ & $\mathbf{F}$ & $\mathbf{M}$ & $\mathbf{F}$ & $\mathbf{M}$ & $\mathbf{F}$ & $\mathbf{M}$ & $\mathbf{F}$ & $\mathbf{M}$ & $\mathbf{F}$ & $\mathbf{M}$ & $\mathbf{F}$ & $\mathbf{M}$ & $\mathbf{F}$ & \\
\hline Br. avellari & - & - & - & - & 5 & 1 & 1 & - & - & 1 & 4 & 2 & 1 & 1 & 2 & - & 9 & - & 22 & 5 & 4.3 \\
\hline Br. mangabeirai & - & - & 1 & - & - & - & - & - & - & - & - & - & - & - & - & - & 1 & - & 2 & - & 0.3 \\
\hline Brumptomyia sp. & - & - & - & 1 & - & - & - & - & - & - & - & - & - & - & - & - & - & 2 & - & 3 & 0.5 \\
\hline Ev. aldafalcaoae & - & - & - & - & - & - & - & - & - & - & - & - & - & - & 1 & - & - & - & 1 & - & 0.2 \\
\hline Ev. corumbaensis & - & - & - & 1 & - & 3 & - & - & - & - & - & - & - & - & - & - & - & - & - & 4 & 0.6 \\
\hline Ev. evandroi & - & - & - & - & 3 & 2 & 4 & 2 & 1 & 4 & 3 & 11 & 4 & 11 & 4 & 4 & 30 & 18 & 49 & 52 & 16.0 \\
\hline Ev. lenti & - & - & 2 & - & 3 & 5 & - & 2 & - & - & 6 & 5 & 2 & 1 & 1 & - & 14 & 1 & 28 & 14 & 6.7 \\
\hline Ev. teratodes & - & - & - & - & - & 1 & - & - & - & - & - & 3 & - & 1 & - & - & - & 2 & - & 7 & 1.1 \\
\hline Ev. termitophila & - & - & - & 2 & 1 & 3 & 3 & 7 & - & 6 & 3 & 19 & 1 & 6 & - & 5 & 5 & 19 & 13 & 67 & 12.7 \\
\hline Ev. (Ald) sp. 1 & - & - & - & - & - & - & - & - & - & - & - & - & - & - & - & - & 1 & - & 1 & - & 0.2 \\
\hline Ev. $(E v a)$ sp. 2 & - & - & - & - & 1 & - & - & - & - & - & 1 & - & - & - & 1 & - & 1 & - & 4 & - & 0.6 \\
\hline Ex.cerradincola & - & - & - & - & 1 & 1 & - & - & - & 1 & - & - & 1 & - & - & 3 & - & 2 & 2 & 7 & 1.4 \\
\hline Lu. cruzi & - & - & - & - & 3 & - & 2 & - & 1 & - & - & - & - & - & 1 & - & - & - & 7 & - & 1.1 \\
\hline Lu. longipalpis & - & - & 1 & - & 1 & - & 1 & - & - & - & - & - & - & - & 1 & - & 3 & - & 7 & - & 1.1 \\
\hline Lu. Longipalpis/cruzi & - & - & 1 & - & 1 & - & - & 1 & - & - & - & - & - & - & - & - & - & 1 & - & 4 & 0.6 \\
\hline Mt. oliveirai & - & - & - & - & 1 & - & - & - & - & - & - & 2 & - & - & - & - & - & 1 & 1 & 3 & 0.6 \\
\hline Mi. echinatopharynx & - & - & - & - & - & - & - & - & - & 1 & - & - & - & - & - & - & - & - & - & 1 & 0.1 \\
\hline Mi.micropyga & - & - & - & - & 1 & - & - & - & - & - & - & - & 1 & - & - & - & - & - & 2 & - & 0.3 \\
\hline Mi. peresi & - & - & - & 2 & 2 & 10 & - & 1 & 1 & 2 & - & 7 & - & 2 & 1 & 2 & 1 & 21 & 5 & 47 & 8.3 \\
\hline Mi. quinquefer & - & - & - & - & 5 & 4 & - & - & - & - & 7 & 4 & - & - & - & - & 6 & 6 & 18 & 14 & 5.1 \\
\hline Ny. whitmani & - & - & 6 & 7 & 26 & 24 & 1 & 5 & 8 & 6 & 21 & 23 & - & 5 & 4 & 1 & 14 & 16 & 80 & 87 & 26.5 \\
\hline Pi.nevesi & - & - & - & 0 & - & - & - & - & - & - & - & - & - & - & - & 1 & - & - & - & 1 & 0.2 \\
\hline$P a$ aragaoi & - & - & - & - & 1 & - & - & - & - & - & 2 & - & - & - & - & - & 2 & 3 & 4 & 4 & 1.3 \\
\hline $\mathrm{Pa}$. brasiliensis & - & - & - & - & 2 & - & - & - & - & - & - & - & - & 1 & - & - & - & - & 3 & - & 0.5 \\
\hline Pa. campograndensis & - & - & - & 1 & - & - & - & - & - & 1 & - & - & 1 & - & - & - & - & - & 2 & 1 & 0.5 \\
\hline Pa. hermanlenti & - & - & - & - & 1 & - & - & - & - & - & - & - & - & - & 1 & - & 1 & 2 & 3 & 2 & 0.8 \\
\hline Pa. shannoni & - & - & 5 & 2 & 5 & - & - & - & - & - & 4 & 1 & - & - & - & - & 9 & 1 & 23 & 4 & 4.3 \\
\hline Ps. hirsutus & - & - & 1 & - & 0 & - & - & - & - & - & - & - & - & - & - & - & - & - & - & 1 & 0.2 \\
\hline Sc. servulolimai & - & - & - & - & - & 3 & - & - & - & - & - & 2 & - & - & - & - & 1 & - & 1 & 5 & 1.0 \\
\hline Sc. sordellii & - & - & - & - & - & 2 & - & - & - & 4 & 1 & 3 & 1 & - & - & 1 & 2 & 5 & 4 & 15 & 3.1 \\
\hline Total & 0 & $\mathbf{0}$ & 15 & 17 & 57 & 60 & 11 & 18 & 11 & 23 & 49 & 81 & 10 & 27 & 15 & 17 & 92 & 100 & 260 & 343 & 100.0 \\
\hline
\end{tabular}

Br: Brumptomyia; Ev: Evamdromyia; Ex: Expapillata; Lu: Lutzomyia; Mt: Martinsmyia; Mi: Micropygomyia; Ny: Nyssomyia; Pi. Pintomyia; Pa: Psathyromyia; Ps: Psychodopygus; Sc: Sciopemyia. Subgenus: Ald: Aldamyia; Eva: Evandromyia; M: male; F: female. 
whitmani, 0.94:1 for Evandromyia evandroi, and 0.19:1 for Evandromyia termitophila.

Of the 29 species analyzed, 27 were present at Mata Comprida settlement, 26 at Laranjeira I, and 20 at Laranjeira II. Regarding the totality of all sandflies collected, 274, 201, and 155 were from Mata Comprida, Laranjeira II and I, respectively. $N y$. whitmani was the most frequent (26.5\%) followed by Ev. evandroi (16\%), and Ev. termitophila (12.7\%). Lutzomyia longipalpis and Lutzomyia cruzi, despite the low frequency $(2.8 \%)$, were captured sympatrically. Two species of the genus Evandromyia were not identified at a specific level, which could be new species. Taxonomic studies will be performed aiming to verify this question, as well as the female of Brumptomyia mangabeirai (Table 1).

Nyssomyia whitmani predominated both in forest (SISA=0.98) and anthropic environments (SISA=0.94) and was in both ecotopes.
Ev. evandroi and Ev. termitophila, the second and the third most frequent species overall, were both in second position at forest environment (SISA=0.87) and anthropic environment (SISA=0.87), respectively. Only Evandromyia aldafalcaoae, Pintomyia nevesi, and Psychodopygus hirsutus were not captured in the forest environment (Table 2).

Table 3 shows that in every settlement, the amount of insects captured in forest environments were higher $(\mathrm{p}<0.01)$ than anthropic environments.

Otherwise, when the intradomicile and peridomicile of these settlements are compared, significant differences $(p<0.01)$ were noted only at Laranjeira I settlement with a large amount of insects in peridomicile areas, as shown in Table 4.

TABLE 2 - Standardized index of species abundance (SISA) for phlebotomines captured in forest and residential areas. Cáceres, State of Mato Grosso, Brazil, from August 2010 to July 2011 ( $n=630)$.

\begin{tabular}{|c|c|c|c|c|c|c|c|c|c|c|}
\hline \multirow[b]{4}{*}{ Species } & \multicolumn{9}{|c|}{ Environments } & \\
\hline & \multicolumn{5}{|c|}{ Forests } & \multicolumn{5}{|c|}{ Anthropic } \\
\hline & Laranjeira I & Laranjeira II & Mata Comprida & SISA & rank & Laranjeira I & Laranjeira II & Mata Comprida & SISA & rank \\
\hline & $\mathbf{n}$ & $\mathbf{n}$ & $\mathbf{n}$ & & & $\mathbf{n}$ & $\mathbf{n}$ & $\mathbf{n}$ & & \\
\hline Br. Avellari & 6 & 6 & 9 & 0.70 & $5^{\text {th }}$ & - & 2 & 4 & 0.37 & $7^{\text {th }}$ \\
\hline Br. Mangabeirai & - & - & 1 & 0.01 & $20^{\text {th }}$ & 1 & - & - & 0.14 & $13^{\text {th }}$ \\
\hline Brumptomyia sp. & - & - & 2 & 0.11 & $15^{\text {th }}$ & 1 & - & - & 0.14 & $13^{\text {th }}$ \\
\hline Ev. aldafalcaoae & - & - & - & 0.00 & $21^{\text {th }}$ & - & - & 1 & 0.02 & $14^{\text {th }}$ \\
\hline Ev. corumbaensis & 3 & - & - & 0.17 & $11^{\text {th }}$ & 1 & - & - & 0.14 & $13^{\text {th }}$ \\
\hline Ev. evandroi & 5 & 14 & 48 & 0.87 & $2^{\text {nd }}$ & - & 11 & 23 & 0.61 & $5^{\text {th }}$ \\
\hline Ev. lenti & 8 & 11 & 15 & 0.82 & $4^{\text {th }}$ & 2 & 2 & 4 & 0.63 & $4^{\text {th }}$ \\
\hline Ev. teratodes & 1 & 3 & 2 & 0.31 & $9^{\text {th }}$ & - & - & 1 & 0.02 & $14^{\text {th }}$ \\
\hline Ev. termitophila & 4 & 22 & 24 & 0.82 & $4^{\text {th }}$ & 2 & 16 & 12 & 0.87 & $2^{\text {nd }}$ \\
\hline Ev. (Ald.) sp. 1 & - & - & 1 & 0.02 & $19^{\text {th }}$ & - & - & - & 0.00 & $15^{\text {th }}$ \\
\hline Ev. (Eva.) sp. 2 & 1 & 1 & 1 & 0.12 & $14^{\text {th }}$ & - & - & 1 & 0.02 & $14^{\text {th }}$ \\
\hline Ex. cerradincola & 2 & - & 2 & 0.24 & $10^{\text {th }}$ & - & 1 & 4 & 0.31 & $8^{\text {th }}$ \\
\hline Lu. cruzi & 3 & - & - & 0.17 & $11^{\text {th }}$ & - & 3 & 1 & 0.23 & $12^{\text {th }}$ \\
\hline Lu. longipalpis & 1 & - & 3 & 0.17 & $11^{\text {th }}$ & 1 & 1 & 1 & 0.26 & $10^{\text {th }}$ \\
\hline Lu. longipalpis/cruzi & 1 & - & 1 & 0.03 & $18^{\text {th }}$ & 1 & 1 & - & 0.24 & $11^{\text {th }}$ \\
\hline Mt. oliveirai & 1 & 2 & 1 & 0.17 & $11^{\text {th }}$ & - & - & - & 0.00 & $15^{\text {th }}$ \\
\hline Mi.echinatopharynx & - & 1 & - & 0.08 & $17^{\text {th }}$ & - & - & - & 0.00 & $15^{\text {th }}$ \\
\hline Mi.micropyga & 1 & - & - & 0.01 & $20^{\text {th }}$ & - & - & 1 & 0.02 & $14^{\text {th }}$ \\
\hline Mi. peresi & 12 & 7 & 22 & 0.84 & $3^{\text {th }}$ & 2 & 4 & 5 & 0.75 & $3^{\text {th }}$ \\
\hline Mi. quinquefer & 9 & 11 & 12 & 0.82 & $4^{\text {th }}$ & - & - & - & 0.00 & $15^{\text {th }}$ \\
\hline Ny. whitmani & 50 & 44 & 30 & 0.98 & $1^{\text {st }}$ & 13 & 20 & 10 & 0.94 & $1^{\text {st }}$ \\
\hline Pi. nevesi & - & - & - & 0.00 & $21^{\text {st }}$ & - & - & 1 & 0.03 & $14^{\text {th }}$ \\
\hline Pa. aragaoi & 1 & 2 & 5 & 0.33 & $8^{\text {th }}$ & - & - & - & 0.00 & $15^{\text {th }}$ \\
\hline Pa. brasiliensis & 2 & - & 1 & 0.14 & $13^{\text {th }}$ & - & - & - & 0.00 & $15^{\text {th }}$ \\
\hline Pa. campograndensis & 1 & 1 & - & 0.10 & $16^{\text {th }}$ & - & - & 1 & 0.02 & $14^{\text {th }}$ \\
\hline Pa. hermanlenti & 1 & - & 3 & 0.16 & $12^{\text {th }}$ & - & - & 1 & 0.02 & $14^{\text {th }}$ \\
\hline Pa. shannoni & 4 & 5 & 10 & 0.67 & $6^{\text {th }}$ & 7 & - & - & 0.30 & $9^{\text {th }}$ \\
\hline Ps. hirsutus & - & - & - & 0.00 & $21^{\text {th }}$ & 1 & - & - & 0.14 & $13^{\text {th }}$ \\
\hline Sc. servulolimai & 3 & 2 & 1 & 0.33 & $8^{\text {th }}$ & - & - & - & 0.00 & $15^{\text {th }}$ \\
\hline Sc. sordellii & 2 & 4 & 7 & 0.51 & $7^{\text {th }}$ & - & 4 & 2 & 0.39 & $6^{\text {th }}$ \\
\hline
\end{tabular}

Br: Brumptomyia; Ev: Evandromyia; Ex: Expapillata; Lu: Lutzomyia; Mt: Martinsmyia; Mi: Micropygomyia; Ny: Nyssomyia; Pi: Pintomyia; Pa: Psathyromyia; Ps: Psychodopygus; Sc: Sciopemyia. Subgenus: Ald: Aldamyia; Eva: Evandromyia; SISA: standardized index of species abundance; n: number. 
TABLE 3 - Numbers of sandflies in anthropic and forest areas in the settlements Laranjeira I, Laranjeira II, and Mata Comprida, municipality of Cáceres, State of Mato Grosso, Brazil, from August 2010 to July $2011(\mathrm{n}=630)$.

\begin{tabular}{|c|c|c|c|c|c|}
\hline \multirow[b]{3}{*}{ Settlements } & \multicolumn{4}{|c|}{ Environments } & \multirow[b]{3}{*}{ Total } \\
\hline & \multicolumn{2}{|c|}{ Anthropic } & \multicolumn{2}{|c|}{ Forest } & \\
\hline & $\mathbf{n}$ & $\%$ & $\mathbf{n}$ & $\%$ & \\
\hline Laranjeira I & 32 & $5.8^{\mathrm{a}}$ & 123 & $19.5^{\mathrm{b}}$ & 155 \\
\hline Laranjeira II & 65 & $10.3^{\mathrm{a}}$ & 136 & $21.6^{\mathrm{b}}$ & 201 \\
\hline Mata Comprida & 73 & $11.6^{\mathrm{a}}$ & 201 & $32.0^{\mathrm{b}}$ & 274 \\
\hline
\end{tabular}

$\mathrm{a,b}$ : Different letters indicate significant differences between the columns; $\mathrm{p}<0.01$

TABLE 4 - Numbers of sandflies in intradomicile and peridomicile areas in the settlements Laranjeira I, Laranjeira II, and Mata Comprida, municipality of Cáceres, State of Mato Grosso, Brazil, from August 2010 to July 2011 (n=630).

\begin{tabular}{|c|c|c|c|c|c|}
\hline \multirow[b]{3}{*}{ Settlements } & \multicolumn{4}{|c|}{ Environments } & \multirow[b]{3}{*}{ Total } \\
\hline & \multicolumn{2}{|c|}{ intradomicile } & \multicolumn{2}{|c|}{ peridomicile } & \\
\hline & $\mathbf{n}$ & $\%$ & $\mathbf{n}$ & $\%$ & \\
\hline Laranjeira I & - & $0.0^{*}$ & 32 & $18.9^{*}$ & 32 \\
\hline Laranjeira II & 30 & 17.6 & 35 & 20.6 & 65 \\
\hline Mata Comprida & 39 & 23.0 & 34 & 20.0 & 93 \\
\hline
\end{tabular}

\section{DISCUSSION}

Light trap captures allowed the identification of 630 sandflies belonging to 28 species, from 11 genera, confirming the large diversity of the phlebotomine sandfly fauna at these three settlements in the municipality of Cáceres, as already reported from other places in the State of Mato Grosso ${ }^{14-16}$.

According to Missawa and Macie ${ }^{17}$ and Amaral et al. ${ }^{18}$, the variety of phlebotomine sandflies found in the State of Mato Grosso is as expected (107 species) considering the diversity of biomes characteristic of the region, such as savannah, Pantanal, transition forest, and the Amazon rainforest.

The data obtained in this research increased our knowledge of these insects fauna in the State, with six species not previously recorded: Brumptomyia avellari, Br. mangabeirai, Evandromyia aldafalcaoae, Micropygomyia echinatopharynx, Micropygomyia peresi, and Psathyromyia campograndensis, raising the current record of species in the State to 112 .

Among the identified species, nine (43\%) presented a wide geographic distribution in Brazil, with Evandromyia evandroi, Lutzomyia longipalpis, Nyssomyia whitmani, and Psathyromyia aragaoi documented in the five Brazilian regions, and the species Brumptomyia avellari, Evandromyia termitophila, Micropygomyia peresi, Psathyromyia brasiliensis, and Psathyromyia hermanlenti are present in the north, northeast, southeast, and midwest regions of the country ${ }^{14}$. The wide area of occurrence of these species can be explained by their adaptation to diverse habitats.

When comparing the number of specimens of each environment (intra, peridomicile, and forest) at the three settlements, we can notice that at anthropized environments (170/27\%), a lower percentage of insects was observed when compared with the forest environment (460/73\%); the higher quantity found in the forest can be explained by the plentiful organic matter of the soil and as this is the natural habitat of these insects ${ }^{19}$. Still, we should consider that it is usual at transmission areas of cutaneous leishmaniasis (CL) to have a destruction of primary forests with subsequent invasion of vectors into the peridomicile environment ${ }^{20}$.

When the ratio of males to females is analyzed, we can notice the predominance of females with $0.81: 1$, contrasting with the result of the several works performed in the midwest region, which reported the reverse, such as Missawa and Dias ${ }^{21}$, that found a male predominance of 1.9:1 at Várzea Grande, MT; Galati et al. ${ }^{22}$ with 1.2:1 at Corumbá, State of Mato Grosso do Sul (MS); Almeida et al. ${ }^{23}$ with 4.8:1 at Ponta Porã, MS; and Nunes et al. ${ }^{24}$ with 5.7:1 at Bonito, MS

Comparing the density of phlebotomine sandflies at the three ecotopes, it is possible to notice a superior frequency and variety of species at Mata Comprida settlement. It is suggested that the largest finding of species (27) and specimens (274) captured at this settlement was due to biotic factors relating to savannah. Also worth pointing out is that this location has banana plantations and various fruit trees, and breeding sites of birds, pigs, horses, and cattle.

Galati et al. ${ }^{25}$ and Oliveira et al. ${ }^{26}$ emphasized the relevance of a sty and chicken coop as places of creation and maintenance of the high density of phlebotomine sandflies in the environment as a risk factor, which should be considered by epidemiological surveillance when planning actions to control the disease.

The settlement Laranjeira II, where savannah is predominant, was the ecotope that presented the second highest index of population density (201) of insects. In this ecosystem, $N y$. whitmani was found in greater numbers compared with the other two settlements, which could be a reflection of greater adaptation to the environment, as this area is the older ecotope (24 years). Few species identified at this place, such as Lutzomyia longipalpis, Evandromyia lenti, Nyssomyia whitmani, Psathyromyia shannoni, Micropygomyia quinquefer, Sciopemyia sordellii, and Ev. termitophila, were also described by Martin and Rebêlo ${ }^{27}$ from a savannah area at Maranhão.

The settlement Laranjeira I was the place with the lowest quantity of phlebotomine sandflies obtained (155) and with 79.3\% of the species captured in the forest area. Of this number, only 32 specimens were attracted by traps set in the peridomicile area. It is a recent settlement located closer to the Boi Morto mountain range, and it is situated at a transition area with Pantanal. Possibly, the specimens still found food and shelter in areas of native forest. Furthermore, it is possible that the sandflies are undergoing adaptation and colonization. Another hypothesis is that the presence of a convex formation and fluvial plain promote high soil moisture due to flooding of the Paraguay River. It is known that this factor is prejudicial to the development of phlebotomine larvae ${ }^{28}$.

Among the species found in this study, we should emphasize Ny. whitmani, Lu. longipalpis, and Lutzomyia cruzi. The first two are efficient vectors of cutaneous and visceral leishmaniasis, respectively, and the last one is implicated as a visceral leishmaniasis (VL) vector. These species are anthropophilic and possess greater ability to adapt to environments modified by man ${ }^{1,29}$. This epidemiological aspect is important as it could explain some cases of a visceral form that occurred among the residents who live at the settlements.

This study indicated the predominance of $N y$. whitmani, which is of public health concern, as this vector is incriminated as a major vector of Leishmania (Viannia) braziliensis in the south, southeast, northeast, and midwest regions of Brazil, and Leishmania (V.) shawi in the north ${ }^{30,31}$ and Leishmania (V.) guyanensis in the Amazon ${ }^{32}$. It is an anthropophilic, exophilic insect frequently found in the forest 
and anthropized environments, with chicken coops and pig sties ${ }^{33,34}$. These characteristics were also observed in the present study area.

The species $N y$. whitmani, besides being the most abundant overall $(167 / 630)$, was most frequently found in the savannah (75.4\%) as discovered in the State of Mato Grosso by Missawa e cols ${ }^{5}$. It is known that cutaneous leishmaniasis is a zoonosis of rural environments ${ }^{35,36}$ similar to the settlements studied here.

Despite the predominance of a forest area (74.2\%) in the three settlements, $N y$. whitmani was present in lower percentages at peridomicile environments $(25.8 \%)$; however, it is worth noticing that this vector is opportunistic and has an eclectic habit for food, adjusting its eating habits to the availability of hosts at anthropic environments ${ }^{37}$. According to Souza et al. ${ }^{38}$, transmission of leishmaniasis can occur in intradomicile and peridomicile environments.

We should note the findings of Lu. longipalpis and $\mathrm{Lu}$. cruzi in sympatry at the settlements Mata Comprida, Laranjeira I and II, similar to the one previously observed by Oliveira et al. ${ }^{34}$ at Campo Grande, MS. Missawa and Lima ${ }^{39}$ conducted studies at 68 of 139 municipalities in MT, and $L u$. longipalpis was reported at 23 of these. This species was found at higher frequency in the savannah, Amazon rainforest, transition, and Pantanal environments, corroborating with the present study.

The finding of Lu. longipalpis at the settlement Mata Comprida at the forest and intradomicile environments, even in low quantity, represents a significant result as this species presents a high vectorial capacity, anthropophily, and an eclectic choice of hosts, besides being the major vector of Leishmania (Leishmania) infantum chagasi in the Americas, including Brazil ${ }^{29}$. The domiciliation of this vector at undeveloped rural areas has become greater due to the modification of the forests and anthropic action, mostly when associated with poor environmental sanitation and low socioeconomic status, as found at the settlements in question ${ }^{40-42}$.

The species $L u$. cruzi has a wide geographic distribution at Mato Grosso, which is found in 24 municipalities but had not previously been reported from Cáceres ${ }^{39}$. Meanwhile, its finding at anthropized environments in Laranjeira II and Mata Comprida has epidemiological importance as it has previously been reported from Jaciara, $\mathrm{MT}^{43}$; Corumbá, MS; and Ladário, $\mathrm{MS}^{44}$. At these municipalities, cases of human and canine visceral leishmaniasis were reported in the absence of Lutzomyia longipalpis, and with a detection of natural infection of $\mathrm{Lu}$. cruzi by Leishmania chagasi indicating, therefore, the participation of these phlebotomines in the transmission of the disease.

Evandromyia evandroi, Ev. termitophila, Ev. peresi, Br. avellari, and $E v$. lenti were all frequently reported in areas close to the animal hosts. However, none of these species is associated with Leishmania spp. ${ }^{14}$ transmission, except Ev. lenti, which has been found naturally infected with Leishmania braziliensis, despite being refractory to experimental infection ${ }^{45,46}$.

The unorganized inhabitation of the environment that is occurring at the settlements Mata Comprida, Laranjeira I and II could lead to domiciliation of the wild population of phlebotomines, including the vectors of leishmaniasis. This highlights the need to carry out further studies to fully understand the dynamic transmission of these diseases in such places.

\section{ACKNOWLEDGMENTS}

The authors thank the residents of the settlements for their permission to carry out this research, the geographer Jaqueline Cochev for the creation of the map, and Josdemar Muniz de Moraes, Sebastião Rodrigues, and Clóvis de Campos Leite from the laboratory of the Regional Health Office of Cáceres (ERSC) for the logistic support. The authors would also like to extend their gratitude to Dr. Daniel Bray for the revision of the manuscript.

\section{CONFLICT OF INTEREST}

The authors declare that there is no conflict of interest.

\section{FINANCIAL SUPPORT}

This study was funded by Coordenação de Aperfeiçoamento de Pessoal de Ensino Superior (CAPES).

\section{REFERENCES}

1. Grimaldi JRG, Tesh RB, McMahon-Pratt D. A review of the geographic distribution and epidemiology of leishmaniasis in the new world. Am J Trop Med Hyg 1989; 41:687-725.

2. Galati EAB. Classificação de Phlebotominae. In: Rangel EF, Lainson R, Orgs. Flebotomíneos do Brasil. Rio de Janeiro: FIOCRUZ; 2003. p. 23-51.

3. Ashford RW. The leishmaniases as emerging and reemerging zoonoses. Int J Parasitol 2000; 30:1269-1281.

4. Ribeiro ALM, Missawa NA, Zeilhofer P. Distribution of phlebotomine sandflies (Díptera: Psychodidae) of medical importance in Mato Grosso state, Brazil. Rev Inst Med Trop Sao Paulo 2007; 4:317-321.

5. Missawa NA, Maciel GBML, Rodrigues H. Distribuição geográfica de Lutzomyia (Nyssomyia) whitmani (Antunes e Coutinho, 1939) no Estado de Mato Grosso. Rev Soc Bras Med Trop 2008; 41:369-373.

6. Mestre GLC, Fontes CJF. A expansão da epidemia da leishmaniose visceral no Estado de Mato Grosso, 1998-2005. Rev Soc Bras Med Trop 2007; 40:42-48.

7. Ferreira JCV. Enciclopédia Ilustrada de Mato Grosso. Cuiabá: Buriti; 2004.

8. Instituto Brasileiro de Geografia e Estatística (IBGE) [Internet]. Rio de Janeiro: IBGE; 2011; [Cited 2011 May 8]. Available from: http://www.ibge.gov.br/ cidadesat/topwindow.htm?1/

9. Alves J, Figueiredo AMR, Bonjour SCM. Os assentamentos rurais em Mato Grosso: Uma análise dos dados do Censo da Reforma Agrária. Panorama Socioeconómico 2009; 27:152-167.

10. Instituto Nacional de Colonização e Reforma Agrária. i3Geo [Internet]. Mato Grosso; 2011; [Cited 2011 April 2] Available from: http://acervofundiario.incra. gov.br/i3geoDes/aplicmap/geral.htm?ff7681 ee332b516d1b3d2c4cb94eac85.

11. Falcão AR. Um novo modelo de armadilha luminosa de sucção para pequenos insetos. Mem Inst Oswaldo Cruz 1981; 76:303-305.

12. Marcondes CB. A proposal of generic and subgeneric abbreviations of phlebotomines sandflies (Diptera: Psychodidae: Phlebotominae) of the world. Entomol News 2007; 118:351-356.

13. Roberts DR, Hsi BP. An index of species abundance for use with mosquito surveillance data. Environ Entomol 1979; 8:1007-1013.

14. Aguiar GM, Medeiros WM. Distribuição e habitats. In: Rangel EF, Lainson R, Orgs. Flebotomíneos do Brasil. Rio de Janeiro: FIOCRUZ; 2003. p. 207-255.

15. De Luca AS, Vasconcelos HL, Barrett TV. Distribution of sandflies (diptera: phlebotominae) in forest remnants and adjacent matrix habitats in brazilian Amazonia. Braz J Biol: 2003; 63:401-410.

16. Ribeiro ALM, Missawa NA, Zeilhofer P. Distribution of phlebotomine sandflies (Diptera: Psychodidae) of medical importance in Mato Grosso state, Brazil. Rev Inst Med Trop São Paulo 2007; 4:317-321. 
17. Missawa NA, Maciel GBML. List of species in the genus Lutzomyia, França, 1924 (Psychodidae, Phlebotominae) from the State of Mato Grosso. Rev Soc Bras Med Trop 2007; 40:11-14.

18. Amaral AFS, VarjãoJR, Silva GB, Arrais-Silva WW. Phlebotomine fauna (Diptera: Psychodidae: Phlebotominae) in a residential area and in a fragment of savanna vegetation in the municipality of Pontal do Araguaia, Mato Grosso, Brazil. Rev Bras Parasitol Vet 2011; 20:165-167.

19. Souza CF, Borges MAZ, Andrade AJ. Contribution to the knowledge of the phlebotomine sand flies fauna (Diptera: Psychodidae) of Timóteo municipality, Minas Gerais, Brasil. Neotrop Entomol 2009; 38:267-271.

20. Lonardoni MVC, Silveira TGV, Alves WA, Maia-Elkhoury ANS, Membrive UA, Membrive NA, et al. Leishmaniose tegumentar americana humana e canina no Município de Mariluz, Estado do Paraná, Brasil. Cad Saude Publica 2006; 22:2713-2716.

21. Missawa NA, Dias ES. Phlebotomine sand flies (Diptera: Psychodidae) in the municipality of Várzea Grande: an area of transmission of visceral leishmaniasis in the state of Mato Grosso, Brazil. Mem Inst Oswaldo Cruz 2007; 102:913-918.

22. Galati EAB, Nunes VL, Rego Junior FA, Oshiro ET, Rodrigues M. Estudo de flebotomíneos (Diptera, Psychodidae) em foco de leishmaniose visceral no Estado de Mato Grosso do Sul, Brasil. Rev Saude Publica 1997; 31:378-390.

23. Almeida PS, Minzão ER, Minzão LD, Silva SR, Ferreira AD, Faccenda O, et al. Aspectos ecológicos de flebotomíneos (Diptera: Psychodidae) em área urbana do município de Ponta Porã, Estado de Mato Grosso do Sul. Rev Soc Bras Med Trop 2010; 43:723-727.

24. Nunes VLB, Galati EAB, Cardozo C, Rocca MEG, Andrade ARO, Santos MFC, et al. Estudo de flebotomíneos (Diptera, Psychodidae) em área urbana do município de Bonito, Mato Grosso do Sul, Brasil. Rev Bras Entomol 2008; 52:446-451.

25. Galati EAB, Nunes VLB, Cristaldo G, Rocha HC. Aspectos do comportamento da fauna flebotomínea (Diptera: Psychodidae) em foco de leishmaniose visceral e tegumentar na Serra da Bodoquena e área adjacente, Estado de Mato Grosso do Sul, Brasil. Rev Pat Trop 2003; 32:235-261.

26. Oliveira AG, Galati EAB, Oliveira O, Oliveira GR, Espindola IAC, Dorval MEC, et al. Abundance of Lutzomyia longipalpis (Diptera: Psychodidae: Phlebotominae) and urban transmission of visceral leishmaniasis in Campo Grande, state of Mato Grosso do Sul, Brazil. Mem Inst Oswaldo Cruz 2006; 101:869-874.

27. Martin AMCB, Rebêlo JMM. Dinâmica espaço-temporal de flebotomíneos (Diptera, Psychodidae) do município de Santa Quitéria, área de cerrado do Estado do Maranhão, Brasil. Iheringia Ser Zool 2006; 96:283-288.

28. Morrison AC, Ferro C, Morales A, Tesh RB, Wilson ML. Dispersal of the sand fly Lutzomyia longipalpis (Diptera: Psychodidae) at an endemic focus of visceral leishmaniasis in Colombia. J Med Entomol 1993; 30:427-435.

29. Lainson R, Rangel EF. Lutzomyia longipalpis and the eco-epidemiology of American visceral leishmaniasis, with particular reference to Brazil - A Review. Mem Inst Oswaldo Cruz 2005; 100:811-827.

30. Costa SM, Cechinel M, Bandeira V, Zannuncio JC, Lainson R, Rangel E. Lutzomyia (Nyssomyia) whitmani s.l. (Antunes e Coutinho, 1939) (Diptera: Psychodidae: Phlebotominae): geographical distribution and the epidemiology of American cutaneous leishmaniasis in Brazil: mini-review. Mem Inst Oswaldo Cruz 2007; 102:149-153.
31. Shaw J. The leishmaniases - survival and expansion in a changing world. A minireview. Mem Inst Oswaldo Cruz 2007; 102:541-547.

32. Rangel EF, Lainson R. Ecologia das leishmanioses. In: Rangel EF, Lainson $\mathrm{R}$, Orgs. Flebotomíneos do Brasil. Rio de Janeiro: FIOCRUZ; 2003. p. 311-327.

33. Galati EAB, Nunes VLB, Dorval MEC, Oshiro ET, Cristaldo G, Espíndola MA et al. Estudo dos flebotomíneos (Diptera, Pychodidae), em área de leishmaniose tegumentar, no Estado de Mato Grosso do Sul, Brasil. Rev Saude Publica 1996; 30:115-128.

34. Oliveira AG, Andrade Filho JD, Falcão AL, Brazil RP. Estudo de flebotomíneos (Diptera, Psychodidae, Phlebotominae) na zona urbana da cidade de Campo Grande, Mato Grosso do Sul, Brasil, 1999-2000. Cad Saude Publica 2003; 19:933-944.

35. Dias ES, França-Silva JC, Silva JC, Monteiro EM, Paula KM, Gonçalves CM, et al. Flebotomíneos (Diptera: Psychodidae) de um foco de leishmaniose tegumentar no Estado de Minas Gerais. Rev Soc Bras Med Trop 2007; 40:49-52.

36. Camargo LB, Langoni H. Impact of leishmaniasis on public health. J Venom Anim Toxins Incl Trop Dis 2006; 12:527-548.

37. Muniz LHG, Rossi RM, Neitzke HC, Monteiro WM, Teodoro U. Estudo dos hábitos alimentares de flebotomíneos em área rural no sul do Brasil. Rev Saude Publica 2006; 40:1087-1093.

38. Souza CM, Pessanha JE, Barata RA, Monteiro EM, Costa DC, Dias ES. Study on Phlebotomine Sand Fly (Diptera: Psychodidae) Fauna in Belo Horizonte, State of Minas Gerais, Brazil. Mem Inst Oswaldo Cruz 2004; 99:795-803.

39. Missawa NA, Lima GB. M. Distribuição espacial de Lutzomyia longipalpis (Lutz e Neiva, 1912) e Lutzomyia cruzi (Mangabeira, 1938) no Estado de Mato Grosso. Rev Soc Bras Med Trop 2006; 39:337-340.

40. Martins LM, Rebêlo JMM, Santos MCFV, Costa JML, Silva AR, Ferreira LA Ecoepidemiologia da leishmaniose tegumentar no Município de Buriticupu, Amazônia do Maranhão, Brasil, 1996 a 1998. Cad Saude Publica 2004, 20:735-743.

41. Missawa NA, Lorosa ES, Dias ES. Preferência alimentar de Lutzomyia longipalpis (Lutz e Neiva, 1912) em área de transmissão de leishmaniose visceral em Mato Grosso. Rev Soc Bras Med Trop 2008; 41:365-368.

42. Montoya-Lerma J, Cadena H, Oviedo M, Ready PD, Barazarte R, Travi BL, et al. Comparative vectorial efficiency of Lutzomyia evansi and Lu. longipalpis for transmitting Leishmania chagasi. Acta Trop 2003; 85:9-29.

43. Missawa NA, Veloso MAE, Maciel GBML, Michalsky EM, Dias ES. Evidência de transmissão de leishmaniose visceral por Lutzomyia cruzi no município de Jaciara, Estado de Mato, Grosso, Brasil. Rev Soc Bras Med Trop 2011; 44:76-78.

44. Santos SO, Arias J, Ribeiro AA, Hoffmann MP, Freitas RA, Malacco MAF. Incrimination of Lutzomyia cruzi as a vector of American visceral leishmaniasis. Med Vet Entomol 1998; 12:315-317.

45. Margonari C, Soares RP, Andrade-Filho JD, Xavier DC, Saraiva L, Fonseca AL, et al. Phlebotomine sand flies (Diptera: Psychodidae) and Leishmania infection in Gafanhoto Park, Divinópolis, Brazil. Entomol Soc America 2010; 47:1212-1219.

46. Brazil RP, Carneiro VL, Andrade Filho JD, Alves JCM, Falcão AL. Biology of Lutzomyia lenti (Mangabeira) (Diptera: Psychodidae). An Soc Entomol Brasil: 1997; 26:191-193. 